\title{
OPTIMALISASI PERAN ORANG TUA DALAM \\ PEMBELAJARAN DARING PADA MASA PANDEMI \\ COVID-19 DI KELURAHAN SUMBER HARTA
}

\author{
Asih Rahmawati, Atika, Indah Novita Wati, \\ Peni Nur Syamsiah dan Yuliana, Muhammad Faizul Amirudin \\ STAI Bumi Silampari Lubuklinggau. \\ asihrahmawati87@yahoo.com,atikaputriasman@gmail.com,indahnovita98 \\ @gamil.com,peninurs96@gmail.com,yuliaana08017@gmail.com. \\ amirudin.mfgcf@gmail.com
}

\begin{tabular}{ll}
\hline Abstrak \\
\hline Article History & Covid-19 has a very bad impact on human \\
Received : 12-08-2020 life. Many activities that are hampered are \\
Revised : 24-10-2020 also limited because of this virus. The \\
Accepted : 28-01-2021 economic, social, political sectors \\
Keycluding education are very affected. As a \\
Covid-19, & result, the world of education must carry \\
Online learning, & out the learning process at home online. \\
The role of parents. & The most basic difference is that students \\
& cannot be directly with the teacher. So that \\
& considering many things that can interfere \\
& with student concentration when learning \\
& from home. Starting from this, it is what \\
& encourages parents to guide their children \\
& to learn with courage. is a challenge for \\
parents. The situation is that parents must \\
be technology literate in order to be able \\
to guide children in school and provide \\
full support for children to be able to learn \\
well during the Covid-19 pandemic. This \\
modern education pattern must still be \\
implemented until conditions are back to \\
conducive.
\end{tabular}

\section{Pendahuluan}

Indonesia dan Negara-negara yang ada di dunia saat ini sedang diterpa dengan berbagai musibah. Salah satu musibah yang paling 
besar dan mengkhawatirkan masyarakat dunia adalah Corona Virus Disease (COVID). Pada akhir tahun 2019, COVID pertama kali muncul di daerah Wuhan yang terletak di negara Cina. Karena COVID muncul pada akhir tahun 2019, maka virus ini dinamakan dengan Covid-19. Covid-19 adalah penyakit menular yang hampir sama dengan penyakit influenza yang disebabkan oleh Severe Acute Respiratory Syndrome Coronavirus 2 (SARS-CoV-2) (Gorbalenya dkk, 2020:15). Penyebaran Covid-19 sangatlah cepat, tidak memandang dari kalangan dewasa bahkan anak-anak dan penyebarannya melalui kontak fisik hidung, mulut dan mata, sehingga berkembang di paru-paru. Tanda-tanda seseorang menggalami Covid-19 adalah suhu tubuh naik, flu, batuk, nyeri ditenggorokan, susah bernafas bahkan dapat mengakibatkan kematian.

Pasca mewabahnya pandemi Covid-19, pemerintah memaksa kita untuk selalu menjaga jarak kepada sesama social distancing dan physical distancing serta menghindari dari kerumunan banyak orang agar dapat mencegah dan memutuskan mata rantai persebaran Covid19. Pada tanggal 24 maret 2020 Menteri Pendidikan dan Kebudayaan Republik Indonesia mengeluarkan Surat Edaran Nomor 4 Tahun 2020 Tentang Pelaksanaan Kebijakan Pendidikan Dalam Masa Darurat Penyebaran COVID, dalam Surat Edaran tersebut dijelaskan bahwa proses belajar dilaksanakan di rumah melalui pembelajaran daring yang diselenggarakan untuk memberikan suatu pengalaman belajar yang bermakna bagi peserta didik di tengah masa pandemic Covid19. Peserta didik tidak bisa lagi bertatap muka secara langsung, bertujuan agar pencegahan terjadinya penularan Covid-19. Belajar di rumah dapat difokuskan pada pendidikan kecakapan hidup antara lain mengenai pandemi Covid-19 (Wahyu, 2020:56).

Pandemi Covid-19 telah merubah berbagai aspek yang ada dalam kehidupan kita, mulai dari ekonomi, sosial, politik bahkan pendidikan. Tentu ada hikmah setiap musibah yang Allah SWT berikan kepada kita, karena wabah penyakit dalam Islam merupakan suatu ketetapan dari Allah SWT, sesuai Firman Allah dalam surat atTaubah ayat 51. (Departemen Agama Islam, 2014:195)

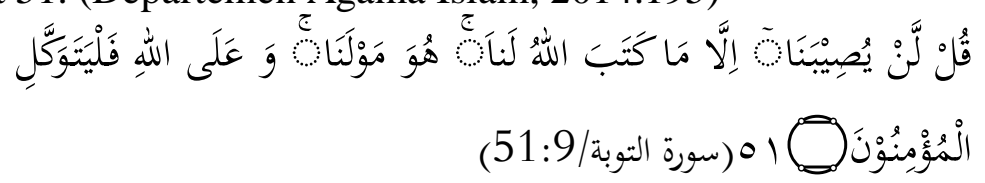


Terjemahan: Katakanlah (Muhammad), "Tidak akan menimpa kami melainkan apa telah ditetapkan Allah untuk kami. Dialah pelindung kami dan hanya kepada Allah orang-orang beriman harus bertawakal.

Penjelasan dari ayat di atas, bahwasannya suatu musibah atau cobaan semua berasal dari Allah SWT dan sudah menjadi ketetapan Allah SWT. Allah SWT adalah sebaik-baik penolong dan pelindung kita bagi orang-orang yang beriman dan bertawakal. Tawakal merupakan poin pertama yang harus diterapkan dalam diri setiap muslim, dengan berserah diri kepada Allah SWT dan tetap selalu berusaha melindungi diri dari penyebaran virus Covid-19.

Saat ini, lembaga pemerintah dan staff lainnya telah membuat peraturan dalam rangka mengalihkan sejenak serta menetapkan semua lembaga pendidikan untuk work from home dan kegiatan belajar dari rumah yang dilakukan dengan cara daring. Kegiatan pembelajaran yang dilaksanakan secara daring nyatanya tidak semudah dibandingkan dengan pembelajaran yang dilaksanakan secara tatap muka. Karena pada pembelajaran daring ini mendesak para guru untuk melakukan inovasi dan adaptasi terkait pemanfaatan teknologi yang tersedia untuk mendukung proses pembelajaran. Pembelajaran yang dilasanakan secara daring, dipilih sebagai suatu konsep yang mendukung untuk digunakan pada masa pandemi Covid-19 ini, serta pembelajaran melalui daring anak harus selalu dibimbing dan diawasi oleh orang tua. Pengawasan dan bimbingan yang diberikan oleh orang tua dalam pembelajaran sangat menentukan keberhasilan suatu pendidikan yang sesuai dengan apa yang direncanakan, meskipun dalam keadaan pandemi Covid-19.

Orang tua merupakan orang yang paling bertanggung jawab dalam mendidik, mengasuh dan membimbing anak-anaknya, sejak lahir hingga tumbuh menjadi dewasa. Adanya pembelajaran yang dilakukan secara daring yang disebabkan karena Covid-19, telah mengajarkan orang tua tentang bagaimana menjadi orang tua seutuhnya. Masa pandemi Covid-19 telah mengembalikan kembali peran orang tua sebagai madrasah pertama bagi anak-anaknya. Orang tua harus dapat memahami pendidikan anak, meskipun pembelajaran dilakukan secara daring dan anak juga harus belajar konsentrasi agar dapat menerima pembelajaran secara maksimal. Tetapi, tidak semua orang tua berperan aktif dalam membimbing anak pada saat pembelajaran daring. Banyak kasus terjadi, beberapa orangtua 
menganggap bahwa pendidikan itu merupakan tanggung jawab pihak sekolah saja.

Saat masa pandemi Covid-19 ini, orang tua sebenarnya memikul beban yang cukup berat, karena semua tugas pembelajaran yang seharusnya diberikan oleh guru di sekolah, kini orang tua yang harus bertanggung jawab terhadap pembelajaran anak secara daring di rumah. Pembelajaran daring juga memaksa para orang tua harus menggunakan teknologi, sehingga suka tidak suka dan mau tidak mau harus belajar dan siap mendampingi melalui jarak jauh dengan menggunakan teknologi. Orang tua harus belajar menyiapkan alat dan sistem pembelajaran jarak jauh dan melakukan bimbingan kepada anak-anak agar bisa menggunakan teknologi dalam pembelajaran untuk meningkatkan kualitas anaknya.

Sumber Harta merupakan salah satu kelurahan yang terdampak adanya pandemi Covid-19, pembelajaran di kelurahan Sumber Harta dilakukan secara daring dan membuat orang tua terasa terbebani. Menurut wawancara Bapak Arifin Amin (Jum'at, 14 Agustus 2020 Pukul 14:00 WIB) selaku Lurah di Kelurahan Sumber Harta, "mayoritas pekerjaan masyarakat di kelurahan Sumber Harta adalah petani dan buruh dan tingkat pendidikan orang tua di kelurahan Sumber Harta $\pm 61 \%$ tamatan SD dan SMP”. Secara tidak langsung pendidikan orang tua dapat mempengaruhi kelangsungan pendidikan bagi anak. Pendidikan orang tua akan memberikan pengaruh terhadap pola berpikir dan orientasi pendidikan yang diberikan kepada anaknya. Semakin tinggi pendidikan yang dimiliki orang tua maka akan semakin memperluas dan melengkapi pola berpikirnya dalam mendidik anaknya.

Pembelajaran yang dilaksanakan secara daring merupakan upaya dalam mempererat jalinan kekeluargaan antara orang tua dan anak. Peran orang tua bertanggungjawab sebagai motivator. Motivasi dapat diberikan dengan cara orang tua berperan sebagai guru di sekolah. Kegiatan belajar anak yang dilaksanakan dirumah disesuaikan dengan kebutuhan anak. Menurut angket yang penulis sebarkan kepada beberapa orang tua, "optimalisasi peran orang tua yang diberikan kepada peserta didik ketika dalam proses pembelajaran adalah kurang optimal yakni $60,2 \% .21,3 \%$ orang tua masih ragu-ragu mendampingi peserta didik saat pembelajaran berlangsung dikarenakan tidak mengerti dalam menggunakan teknologi, $18,5 \%$ orang tua sudah siap untuk mendampingi peserta 
didik dalam proses pembelajaran". Seharusnya orang tua harus menjadikan proses pembelajaran daring ini menjadi lebih efektif dan menarik. Saat ini sudah \pm 6 Bulan pembelajaran daring berlangsung, membuat anak menjadi bosan dan jenuh dan anak-anak juga rindu terhadap proses pembelajaran yang dilakukan secara tatap muka di sekolah.

Hal ini, menjadi kritikan keras bagi orang tua dalam mendampingi anaknya saat proses pembelajaran. Padahal kenyataannya para orang tua yang ada di Kelurahan Sumber Harta memiliki pekerjaan yang tidak bisa ditinggalkan, mereka pun bekerja dari pagi sampai sore hari. Sedangkan pembelajaran daring dilakukan pada pagi sampai siang hari saja. Minimnya waktu yang diberikan para orang tua dalam membimbing dan mengawasi proses pembelajaran anak di rumah.

Pembelajaran daring yang dilakukan oleh anak-anak di Kelurahan Sumber Harta sangat perlu pengawasan yang ekstra, dikarenakan anak-anak apabila telah menggunakan handphone seringkali lupa tugas yang seharusnya dikerjakan, anak-anak malah sibuk dengan permainan game dan aplikasi lainnya yang ada di handphonenya. Dalam hal ini orangtua menjadi sosok guru yang mampu memotivasi anak di rumah, dalam memberikan kegiatan anak dirumah orang tua memiliki peran sebagai pendidik yang utama. Kegiatan yang diberikan kepada anak di sesuaikan dengan tingkat perkembangan anak, berkolaborasi dengan guru juga berperan aktif dalam memberikan kegiatan pembelajaran orang tua bertindak sebagai pelaksanaan kegiatan pembelajaran.

\section{Metode Penelitian}

Penelitian ini menggunakan penelitian kualitatif field research. Menurut Lexy Metode ini menjelaskan memahami fenomena yang dialami oleh subjek penelitian seperti perilaku, persepsi, motivasi, tindakan, dan lain-lain, secara holistik dan melalui uraian berupa kata-kata dan bahasa, dengan cara yang natural. konteks dan dengan memanfaatkan berbagai metode". (Lexy, 2018: 6.) Teknik pengumpulan data yang saya lakukan adalah dengan observasi, wawancara, dan dokumentasi tentang memfokuskan pada beberapa kegiatan untuk mengoptimalisasikan peran orang tua dalam pembelajaran daring pada masa pandemi Covid-19. 


\section{Pembahasan}

\section{Peran Orang Tua dalam Pembelajaran Daring}

Pembelajaran daring atau biasa disebut dengan pembelajaran jarak jauh yang dilakukan di rumah merupakan sebuah metode pembelajaran yang harus dilaksanakan semua peserta didik yang terdampak Covid-19. Proses belajar mengajar pada saat daring memanfaatkan jaringan internet dalam proses pelaksanaannya, peserta didik dapat berkomunikasi secara virtual dengan para guru menggunakan aplikasi-aplikasi yang ada di handphone seperti google meet, live chat, zoom, whatsapp, quiziz dan aplikasi-aplikasi lainnya. Proses belajar mengajar secara daring dikembangkan dengan tujuan memperluas jangkauan layanan pendidikan dan juga meningkatkan ketersediaan layanan pendidikan yang terjadi pada masa pandemi Covid-19 (Lia Nur, 2020:46). Meskipun terlihat menyenangkan, ternyata pembelajaran daring yang dilaksanakan dari rumah bukanlah sesuatu yang mudah untuk dilaksanakan. Selama belajar dari rumah, siswa banyak mendapatkan tugas sehingga peserta didik dan orang tua tidak siap dan merasa kebinggungan untuk melaksanakan pembelajaran daring.

Berdasarkan hasil observasi yang penulis lakukan bahwa pembelajaran yang dilaksanakan oleh siswa yang ada di Kelurahan Sumber Harta juga menggunakan pembelajaran daring atau pembelajaran jarak jauh. Banyak sekali aplikasi yang dapat digunakan untuk menunjang terlaksananya proses pembelajaran daring, tetapi pada kenyataannya proses pembelajaran daring yang terjadi di Kelurahan Sumber Harta hanya menggunakan aplikasi whatsapp saja, aplikasi whatsapp merupakan aplikasi yang mudah untuk dipelajari oleh peserta didik dan para orang tua dalam pembelajaran daring ini, dikarenakan belum mengerti bagaimana cara menggunakan aplikasi-aplikasi yang lainnya para orang tua sudah terbiasa belajar menggunakan buku paket saja. Pembelajaran daring yang dilaksanakan juga masih kurang efektif, dikarenakan peserta didik yang kurang tanggap dengan adanya teknologi sebagai alat dari pembelajaran daring itu sendiri. Banyak juga, hal yang menjadi penghambat proses pembelajaran daring ini, misalnya jaringan internet yang tidak merata, akses internet yang mahal, bahkan ada yang belum memiliki akses internet sama sekali, masih banyak juga peserta didik yang tidak mempunyai handphone karena keterbatasan ekonomi serta kurangnya pengawasan yang diberikan oleh orang tua. 
Hasil wawancara yang dilakukan penulis ke 15 orang tua dari berbagai sekolah yang ada di Kelurahan Sumber Harta. Para orang tua menjelaskan tentang keluhan yang dialami sejak diterapkannya proses pembelajaran secara daring. Pembelajaran daring hanya membuat beban hidup bertambah saja, apalagi saat ini pembelajaran daring masih terus diperpanjang. Penjelasan 13 dari 15 orang tua yang anaknya mengalami pembelajaran daring mengatakan selama ini anak kami disekolahkan agar dapat menerima pembelajaran secara maksimal dan dapat menjadi orang pintar tidak seperti kami. Tetapi, kondisi saat ini menjadikan orang tua harus dapat membimbing anakanaknya saat pembelajaran berlangsung, banyak hambatan-hambatan yang diterima oleh orang tua peserta didik. Mayoritas pendidikan di Kelurahan Sumber Harta hanya tamat SD sampai SMP saja, sedangkan untuk menggunakan teknologi mereka cenderung tidak pernah. Pembelajaran daring ini memaksa orang tua untuk berusaha belajar dalam memanfaatkan teknologi handphone secara benar dan sesuai dengan tujuan dari pembelajaran daring ini sendiri.

Padahal pembelajaran yang dilakukan secara daring merupakan upaya dalam mempererat jalinan kekeluargaan antar orang tua dan peserta didik. Hikmah dari adanya pandemi Covid-19 yang terjadi di Indonesia adalah dapat mengembalikan kembali peran orang tua sebagai madrasah pertama bagi anak-anaknya. Kontribusi orang tua dalam proses pembelajaran daring untuk anaknya sangatlah penting, dengan cara membimbing, memotivasi, memberi arahan dan membantu ketika peserta didik mengalami kesulitan. Dalam Firman Allah Surat at-Tahrim ayat 6. (Departemen Agama Islam, 2014:560)

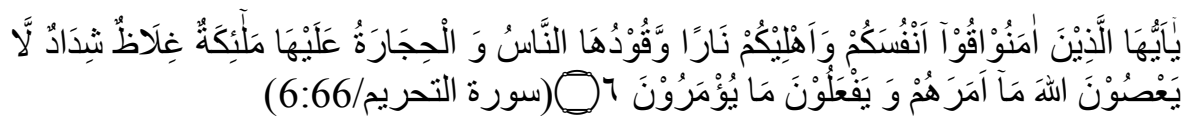

Terjemahan: Wahai orang-orang yang beriman! Perihalah dirimu dan keluargamu dari api neraka yang bahan bakarnya adalah manusia dan batu, penjaganya malaikat-malaikat yang kasar dan keras, yang tidak durhaka kepada Allah terhadap apa yang Dia perintahkan kepada mereka dan selalu mengerjakan apa yang diperintahkan.

Ayat di atas menjelaskan bahwa orang tua mempunyai kewajiban dalam melindungi, membimbing dan mengarahkan anakanaknya dengan dasar aqidah, akhlak dan keilmuan yang akan 
mengantarkan mereka menuju keberhasilan, baik didunia dan diakhirat. Keluarga merupakan pondasi pendidikan pertama bagi anak, masa pandemi Covid-19 menjadikan orang tua bertindak sebagai pelaksana pembelajaran di rumah dan sekaligus menjadi guru pengganti sementara. Orang tua merupakan madrasah pertama bagi anak-anak mereka, karena orang tualah yang memberikan dan menanamkan pendidikan dasar bagi anak-anaknya. Orang tua juga memiliki tanggung jawab penuh terhadap perkembangan dan prestasi anak. Motivasi belajar daring dari orang tua merupakan bentuk nyata pentingnya peran orang tua terhadap pendidikan anak-anaknya, sehingga program pemerintah terhadap pembelajaran daring dapat terlaksana secara efektif.

Adanya kegiatan pembelajaran di rumah ini pun memiliki manfaat bagi peserta didik maupun orang tuanya, kebijakan pemerintah mengenai pembelajaran daring ini membuat kita semua sadar akan pentingnya mempelajari teknologi dan menggunakan teknologi secara positif. Sisi lain dari pembelajaran daring ini membuat orang tua menjadi lebih dekat secara emosional dengan anak-anak mereka, orang tua juga lebih bisa mendampingi dan mengawasi anak belajar dari rumah, sambil orang tua mengerjakan pekerjaan yang harus diselesaikan baik dari kantor atau harus bekerja dari rumah atau karena pekerjaan rutin lainnya yang menjadi tantangan tersendiri dalam menghadapi pembelajaran daring. Namun, perlu dingat bahwa peran orang tua dalam membimbing anak belajar di rumah bukan berarti untuk menggantikan semua peran guru di sekolah, tetap ada beberapa hal yang harus di handle oleh guru di sekolah.

Kondisi yang berupa latar belakang pendidikan orang tua merupakan satu hal yang dapat mempengaruhi keberhasilan pembelajaran anak. Peran orang tua dalam mendampingi kesuksesan anak selama belajar di rumah menjadi sangat sentral. Menurut Hasan, peranan orang tua bagi pendidikan anak adalah memberikan dasar pendidikan, sikap dan keterampilan dasar, seperti pendidikan agama, budi pekerti, sopan santun, estetika, kasih sayang, rasa aman, dasardasar untuk mematuhi peraturan, dan menanamkan kebiasaan (Siti, 2019:5). Anak diibaratkan sebagai kertas putih yang tidak ada noda sama sekali menurut teori tabularasa, orang tualah yang akan menjadikan seorang anak itu menjadi pribadi yang baik atau buruk. 
Dampak yang dirasakan oleh orang tua di Kelurahan Sumber Harta dalam sistem pembelajaran jarak jauh melalui sekolah daring juga cukup beragam. Orang tua harus menambah beban pengeluaran untuk memberikan fasilitas yang memadai bagi anak agar dapat mengikuti pembelajaran secara daring. Untuk melaksanakan sekolah dengan sistem pembelajaran daring yang sampai saat ini belum dapat diketahui akan berlangsung sampai berapa bulan ke depan, tentunya mengharuskan orang tua untuk menyediakan setidaknya kuota internet yang cukup banyak ataupun dengan berlangganan jaringan WiFi yang tidak murah semata-mata agar proses belajar secara daring yang dilakukan oleh anak dapat berlangsung dengan lancar.

Dampak selanjutnya yang harus dihadapi oleh orang tua di Kelurahan Sumber Harta dalam pelaksanaan pembelajaran jarak jauh melalui metode pembelajaran daring ini yaitu berkaitan dengan waktu. Orang tua diharapkan dapat mendampingi anak dalam melakukan pembelajaran daring, karena anak belum tentu bisa mengakses dan menyerap materi serta tugas-tugas dari pembelajaran daring ini sendiri, sehingga orang tua harus hadir dalam mengawasi dan memberi perhatian kepada anak baik pada saat sebelum pembelajaran dimulai, saat pembelajaran berlangsung, sampai dengan setelah pembelajaran selesai. Agar isi dan materi dari pembelajaran daring tersebut tidak sia-sia. Hal ini tentu saja akan sangat berpengaruh terhadap waktu yang dimiliki orang tua untuk melaksanakan aktivitas pribadinya seperti bekerja, kegiatan rumah tangga dan lain sebagainya. Banyak pula cerita pengalaman negatif orang tua siswa selama mendampingi anak-anaknya belajar. Seperti misalnya ada orang tua siswa yang sering meluapkan emosinya dengan marah-marah karena mendapati anaknya yang sulit diatur sehingga mereka tidak tahan dan menginginkan anak mereka belajar kembali di sekolah.

Pembelajaran secara daring dalam waktu yang panjang juga akan berdampak negatif pada psikologis baik peserta didik maupun orang tua di Kelurahan Sumber Harta. Pada akhir maret lalu, "dilansir dari CNN Indonesia Nasional (2020), menurut peneliti dari Hong Kong Christopher Yu Wing-fai mengatakan bahwa 85\% orang tua mengaku stres dan tidak senang dengan penutupan sekolah, dikarenakan anak mengalami kesulitan saat pembelajaran daring dan orang tua juga merasa khawatir dengan perkembangan belajar anak. Pembelajaran yang dilakukan secara daring tidak sepenuhnya dapat 
memenuhi kebutuhan setiap individu. Dalam proses pembelajaran di rumah atau pembelajaran jarak jauh ini, anak-anak di Kelurahan Sumber Harta mengalami stress, sedih, bosan, jenuh dan perasaan lainnya. Setiap orang tua pasti memiliki peran yang sangat dibutuhkan oleh anaknya, peran orang tua adalah menjadikan anak agar mampu berpartisipasi aktif ketika proses pembelajaran daring, sehingga proses pembelajaran akan berlangsung dengan baik sesuai dengan apa yang diharapkan. Dengan adanya peran orang tua sebagaimana di atas, akan menjadikan dampak positif bagi anak, sehingga anak akan memiliki sifat percaya diri dan mampu menghadapi pembelajaran yang belum pernah mereka temukan sebelumnya (Subarto, 2020:16).

Di Kelurahan Sumber Harta, dorongan dan dukungan orang tua dalam kegiatan belajar di rumah dikombinasikan dengan keterlibatan guru pada pemberian materi belajar sangat penting untuk keberlangsungan pendidikan anak. Untuk anak sebagai peserta didik usia kelas Sekolah Dasar masih sangat dibutuhkan bantuan orang tua untuk mendampingi dan memantau pembelajaran jarak jauh melalui sekolan daring di rumah. Minimal untuk membantu mempersiapkan sarana dan prasarana media teknologi baik sebelum dan sesudah pelaksanaan proses pembelajaran daring berlangsung, sehingga anak sebagai peserta didik dapat mengikuti pembelajaran daring dengan efektif, tepat waktu dan tidak kesulitan dalam mengakses materi belajar. Dengan demikian dukungan dan kerjasama orang tua demi keberhasilan pembelajaran jarak jauh melalui sekolah daring sangat dibutuhkan.

Peran orang tua bagi anaknya adalah sebagai sentral pendidikan utama dalam membimbing dan memberikan ilmu pengetahuan dengan tujuan agar anak dapat tumbuh dan menjadi pintar seperti apa yang dicita-citakan. Menurut Endang Winingsih (2020) terdapat empat peran orang tua selama pembelajaran daring atau pembelajaran jarak jauh, yaitu: 1) Orang tua memiliki peran sebagai guru di rumah, yang di mana orang tua dapat membimbing anaknya dalam belajar secara jarak jauh dari rumah. 2) Orang tua sebagai fasilitator, yaitu orang tua sebagai sarana dan pra-sarana bagi anaknya dalam melaksanakan pembelajaran jarak jauh. 3) Orang tua sebagai motivator, yaitu orang tua dapat memberikan semangat serta dukungan kepada anaknya dalam melaksanakan pembelajaran, 
sehingga anak memiliki semangat untuk belajar, serta memperoleh prestasi yang baik. 4) Orang tua sebagai pengaruh atau director.

Dapat disimpulkan, bahwa peran orang tua sangatlah menentukan terhadap pembelajaran anak di rumah. Peran orang tua sebagai guru nomor satu yang membimbing, sebagai fasilitator yang menyediakan sarana dan prasarana yang mendukung proses terlaksananya pembelajaran daring, sebagai motivator bagi anaknya yang dapat menjadi penggerak dan pendorong dalam meningkatkan motivasi belajar dan terakhir sebagai pengarah yang selalu membimbing anaknya dalam mencapai keberhasilan di masa yang akan datang. Dan orang tua juga berperan untuk mengarahkan anakanaknya sesuai dengan bakat dan minat yang dimiliki selama proses pembelajaran daring berlangsung.

\section{Optimalisasi Peran Orang Tua dalam Pembelajaran Daring}

Orang tua mempunyai sebuah tanggung jawab yang berat dalam mendidik anaknya, orang tua juga menjadi mitra sekolah yang berperan dalam meningkatkan mutu pendidikan anak. Melalui orang tua, kegiatan belajar anak dapat dipantau, tetapi keadaan di Kelurahan Sumber Harta, orang tua tidak sepenuhnya dapat membimbing dan mengawasi anak dalam mengikuti pembelajaran daring.

Menanggapi hal tersebut, Pertama, penulis mengadakan kegiatan forum webinar bagi orang tua di Kelurahan Sumber Harta. Menurut Mansyur, webinar adalah suatu seminar, presentasi, pengajaran ataupun workshop yang dilakukan secara online, tatap muka secara online yang disampaikan melalui media internet dan dapat dihadiri oleh banyak orang yang berada dilokasi yang berbedabeda, pada kegiatan webinar seseorang dapat berinteraksi secara langsung melalui gambar (video) ataupun teks (Sofia Slivianita \& Eko Yulianto, 2020:115). Adapun kelebihan penggunaan webinar adalah hemat biaya, sangat fleksibel, dapat berinteraksi dengan banyak orang dan dapat belajar secara langsung.

Webinar ini berlangsung pada tanggal 06 September 2020 dengan topik "Optimalisasi Peran Orang Tua Dalam Pembelajaran Daring Pada Masa Pandemi Covid-19 Di Kelurahan Sumber Harta". Narasumber dalam kegiatan ini yaitu ibu Eva Marliah Ningsih, M. Pd. yang merupakan salah satu dosen di Sekolah Tinggi Bumi Silampari Lubukinggau sekaligus sebagai dosen ahli dalam bidang 
Psikologi. Pemilihan narasumber pada webinar ini adalah bentuk perwujudan dari tema yang telah dibuat. Melalui kegiatan seminar ini diharapkan dapat membuka mindset wawasan, dan menjadi jalan bagi orang tua dalam menjalankan perannya masing-masing sebagai perantara pembelajaran bagi anak-anaknya baik di rumah maupun di sekolah dalam era pembelajaran new normal. Sehingga orang tua dapat mengatasi permasalahan yang muncul ketika belajar dari rumah agar nantinya tujuan pendidikan dapat tetap tercapai.

Di masa pandemi seperti ini orang tua tentu harus berperan lebih aktif terhadap anak-anaknya. Menurut Eva Marliah Ningsih, "penting bagi kita semua belajar terkait dengan peranan dalam pembelajaran di Era New Normal ini". Topik webinar tentang optimalisasi peran orang tua dianggap penting karena perlunya pengetahuan orang tua mengenai peranannya dan juga hal-hal yang berhubungan dengan pembelajaran dari rumah.

Menurut Euis Kurniati, peran orang tua dalam membimbing peserta didik saat proses pembelajaran dari rumah selama masa pandemi Covid-19 diantaranya yaitu: sebagai pendamping, penjaga, pengembang dan pengontrol anak, agar anak dapat melaksanakan dengan mudah dan nyaman ketika mengerjakan tugas yang diberikan oleh guru di sekolah, orang tua juga dapat melakukan aktifitas secara bersama serta dapat mewujudkan lingkungan yang aman dan asyik yang membuat anak tidak cepat merasa bosan dan orang tua harus selalu memberikan edukasi yang menciptakan pembelajaran secara bervariasi dan berinovasi selama kegiatan pembelajaran dilaksanakan dari rumah (Euis Kurniati, dkk, 2020:253).

Selain itu, orang tua juga dituntut untuk lebih dekat dengan anak. Orang tua diharapkan untuk mendampingi anak saat proses belajar dan membantu memberikan pemahaman pada anak tentang apa yang ia pelajari secara daring. Hal ini bertujuan untuk menciptakan keseriusan dan pengawasan terhadap proses belajar. Dengan dialihkannya pembelajaran dari sekolah ke rumah, bukan berarti guru mengalihkan tanggung jawab sepenuhnya kepada orang tua, tetapi ini adalah tentang kerjasama, sinergitas antara guru dan orang tua. Optimalisasi peran orang tua dalam pendampingan anak belajar dari rumah hanya mungkin bisa dicapai apabila dapat saling memahami antara guru dan orang tua.

Meskipun peran orang tua begitu kompleks, orang tua diharapkan tidak mengambil alih peran murid. Tugas yang 
seharusnya dikerjakan murid, dikerjakan oleh orang tua, dengan asumsi yang penting tugas tersebut dikumpulkan sesuai waktu yang di tentukan, dengan kualitas baik. Dan yang terpenting, agar anak memperoleh nilai yang tinggi. Hal ini tidak hanya melanggar peran dalam proses sinergi orang tua dan guru, tetapi juga merusak mental dan psikologis anak dalam jangka panjang. Andaipun anak akhirnya mendapat nilai tinggi dari penugasan, tetapi nilai tersebut tidak mencerminkan kompetensinya. Dengan memahami perannya secara baik, hal-hal yang demikian akan lebih dapat diminimalisir.

Kegiatan seminar ini diikuti oleh 11 orang yang terdiri dari Narasumber, Moderator dan para orang tua. Dalam penyampaiannya, ibu Eva Marliah Ningsih, M. Pd sebagai narasumber mengungkapkan bahwa anak-anak perlu memiliki cita-cita sejak kecil, dan orang tua perlu memberikan pengalaman baru supaya menjadi pijakan dan panutan anak untuk memiliki cita-cita, Walaupun pada masa pandemi pembelajaran tidak bisa dilakukan secara tatap antara guru dan peserta didik.

Lebih lanjut Ibu Eva Marliah Ningsih, M. Pd memaparkan tentang bagaimana memaksimalkan peran orang tua sela ma pelaksanaan belajar dari rumah adalah dengan cara memperhatikan situasi dan kondisi diantaranya, pahami dan kenali kondisi anak dari mulai gaya belajar dan situasi emosi yang juga dapat dilakukan dengan membuat rencana manajemen waktu belajar bersama anak ketika dirumah. Mendiskusikan dan menyepakati aturan belajar dari rumah melalui komunikasi yang positif untuk menciptakan motivasi belajar serta memberikan pengawasan dan evaluasi terhadap proses dan hasil belajar anak. Orang tua juga perlu menerapkan pembiasaan membaca dan menyiapkan buku bacaan, serta melakukan kegiatan belajar bersama antara orang tua dan anak menjadi hal pokok untuk dilakukan pada saat pembelajaran daring. Selain itu juga dalam proses pembelajaran daring ini, orang tua perlu mengedepankan rasa sabar, perhatian dan harus terus belajar dalam mengelola emosi dengan baik agar anak dapat merasa nyaman dan tidak tertekan.

Pelaksanaan belajar dari rumah memang perlu memperhatikan kesehatan mental anak, selain itu juga perlu mengatur jadwal kegiatan belajar, konsistensi orang tua dalam mendampingi anak, dan kerjasama dengan guru, serta juga tidak kalah pentingnya adalah mendidik anak dengan cinta dan kasih sayang orang tua sesuai 
dengan semestinya bahwa orang tua adalah pendidik pertama dan yang utama bagi anak-anaknya. Peran yang sudah ditinggalkan sekian lama dan harus di ambil kembali karena adanya pandemi covid-19 ini, harus terus dipertahankan bahkan saat pandemi ini berakhir, selaras dengan itu maka dapat tercapai tujuan pembelajaran sekolah yang telah di tetapkan. Dengan masih diberlakukannya pembelajaran dari rumah di sebagian besar sekolah, orang tua harus mampu berperan sebagai guru bagi anak di rumah.

Dalam pelaksanaan webinar ini banyak kendala yang dihadapi, baik kendala internal maupun kendala eksternal. Adapun kendala yang penulis hadapi diantaranya adalah kurangnya antusias para orang tua dalam mengikuti kegiatan webinar ini, dikarenakan mayoritas orang tua memiliki tingkat pendidikan yang rendah dan banyak orang tua yang tidak memiliki alat komunikasi handphone dan adapun orang tua yang memiliki handphone namun banyak diantara orang tua yang tidak mengetahui cara mengoprasikan alat komunikasi tersebut. Selain faktor fasilitas seperti handphone, kendala lain yang penulis hadapi yaitu keberagaman profesi orang tua yang mayoritas sebagai petani karet yang aktifitasnya dimulai dari pagi hari sampai siang hari, sehingga para orang tua tidak memiliki cukup waktu untuk mengikuti acara seperti ini.

Dari beberapa permasalahan yang terjadi, penulis akhirnya mampu mengajak dan memotivasi orang tua untuk mengikuti webinar yang diselenggarakan oleh penulis. Namun, ketika kegiatan sedang berlangsung, penulis mengalami permasalahan, yaitu masalah jaringan internet yang kurang memadai, sehingga untuk mengakses aplikasi Zoom yang digunakan sebagai media webinar hanya bisa dilakukan oleh orang tua yang berada diarea tertentu.

Dengan pelaksanaan webinar itu maka orang tua mempunyai pengetahuan dan wawasan baru mengenai bagaiman seharusnya peran orang tua dalam pembelajaran daring pada masa pandemi covid-19. Orang tua menyadari bahwa perannya sangat dibutuhkan dalam membantu terlaksananya pembelajaran dari rumah dengan baik. Dengan demikian diketahui bahwa peran orang tua bukan hanya sebatas memberikan fasilitas belajar bagi anak-anaknya, melainkan juga memberikan support berupa pendampingan, bimbingan, motivasi, dan quality time bersama anak serta orang tua juga mampu mengevaluasi cara dan hasil belajar anak. Perlunya pendampingan yang diberikan oleh orang tua sangat menentukan pencapaian hasil 
belajar anak yang sesuai dengan tujuan pembelajaran daring. Orang tua juga dituntut untuk dapat menjalin kerja sama dengan para guru di sekolah dalam memotivasi anak agar dapat melaksanakan pembelajaran daring secara maksimal dan banyak sekali arahan yang diberikan oleh narasumber di dalam mensukseskan pembelajaran daring.

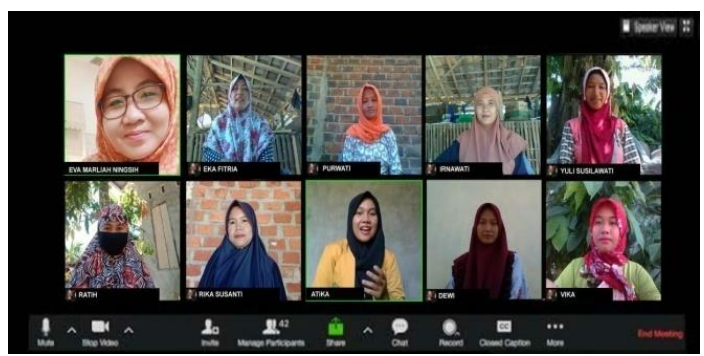

Gambar 2.

Keadaan forum edukasi melalui webinar yang diberikan kepada orang tua

Dapat disimpulkan bahwa, kegiatan forum webinar ini merupakan salah satu bentuk kegiatan untuk mengoptimalisasikan peran orang tua dalam pembelajaran daring. Kegiatan forum webinar yang dilakukan menjadi pelajaran baru bagi orang tua dalam membimbing, mendidik dan mengawasi anak selama proses pembelajaran daring berlangsung. Sehingga, anak tidak merasa mendapatkan tekanan dari guru yang memberikan tugas dan tekanan dari orang tua yang hanya menuntut anaknya agar segera menyelesaikan tugas yang diberikan.

Kedua, kegiatan yang dilakukan dengan sosialisasi secara langsung kepada para orang tua di Kelurahan Sumber Harta dengan tetap mematuhi aturan protocol kesehatan covid-19. Pada hari Senin, 7 September 2020, penulis melaksanakan sosialisasi mengenai "Seberapa penting peran orang tua terhadap keberhasilan anak dalam proses pembelajaran daring." Penulis mengajak para warga sekitar untuk berkumpul di halaman rumah salah satu warga yakni di halaman rumah Ibu Dewi Wulandari pada pukul 09.00 WIB. Ibu-ibu yang telah menerima undangan secara Online (melalui Whatshapp) pada hari sebelum pelaksanaan hadir dalam sosialisasi ini dengan penuh apresiasi serta semangat yang tinggi untuk menerima materi yang akan di sampaikan oleh penulis. Pentingnya sosialisasi ini di karenakan sosialisasi sendiri memiliki arti sebuah proses penanaman atau transfer kebiasaan atau nilai dan aturan dari satu generasi ke 
generasi lainnya dalam sebuah kelompok atau masyarakat (Fachri Muhammad, 2015:314)

Dalam kesempatan sosialisasi ini, peserta Kukerta menyampaikan materi mengenai hal-hal yang harus dilakukan oleh, orangtua dalam mendampingi peserta didik belajar pada masa covid19 atau di rumah, yang telah terangkum sebagai berikut: Yang pertama, Membuat rencana target belajar anak. Situasi belajar di rumah memang kurang ideal seperti belajar disekolah. Untuk itu orang tua perlu membuat adaptasi dan target belajar yang realistis sesuai dengan kondirsi rumah. Misalnya faktor ganguan seperti adanya saudara yang dapat mengganggu kegiatan belajar, sarana dan prasarana belajar daring.

Adapaun yang kedua, Menjalankan kebiasaan yang sama dan ajarkan tanggung jawab. Walaupun hanya di rumah, upayakan peserta didik menjalankan tugas rutinitas harian yang sama ketika belajar di sekolah. Seperti bangun pagi, melakukan kegiatan belajar mengajar daring atau luring, baru setelahnya anak dapat bermain. Hal ini perlu dilakukan agar anak lebih nyaman, aman dan tidak cemas terhadap perubahan situasi belajar yang ada. Orang tua harus mengajarkan anggung jawab kepada peserta didik terhadap tugas sekolahnya selama belajar di rumah. Yang ketiga adalah Sabar. Selama beajar dirumah, orang tua akan menjadi tutor bagi anak yang mengantuikan guru. Untuk itu perlu kesabaran dalam membimbing anak belajar. Selain itu berikanllah pengajaran dengan kasih sayang. Tujuannya adalah agar anak merasa nyaman dan aman dengan situasi belajar di rumah terutama di masa pademi.

Yang keempat yakni, Memanfaatkan aplikasi. Perkembangan teknologi masa kini dapat membuat para orangtua harus mengunakan beberapa apliksi untuk membantu metode anak belajar. Apalagi anakanak pada masa kini lebih menyukai pembelajaran yang memiliki animasi visual dan audiotori yang menyenangkan. Sehingga orangtua tidak sealalu memberikan materi pembelajaran secara konvesional. Dan yang kelima yaitu Mempelajari kekuatan dan kelemahan anak. Mengetahui kekuatan dan kelemahan anak untuk belajar sangat penting agar materi pembelajaran mudah di serap olehnya. Orang tua perlu kreatif dalam menggunakan media apapun untuk proses belajar di rumah. Misalnya memanfaatkan video tutorial online atau modul berbasis tulisan dan gambar. 
Dari penyampaian materi penulis di atas, ada beberapa orang tua yang menyampaikan realita yang terjadi ketika sedang membersamai dan mengarahkan anak pada saat pembelajaran daring. Orang tua tidak memiliki kesabaran yang ekstra ketika mendampingi anak pada saat pembelajaran daring, sehingga orang tua mengalami kesulitan dan tak banyak orang tua juga mengalami emosi yang akhirnya berujung kemarahan. Semestinya orang tua harus menjadi uswatun hasanah kepada anak-anaknya, hal serupa menjelaskan bahwasannya orang tua sudah mengalami kesusahan dan bosan dengan proses belajar mengajar secara daring serta mengakibatkan ketidaksungguhan orang tua ketika mendampingi anak belajar dari rumah (Tabiin, 2020:60). Ketidaksungguhan menjadi salah satu kekeliruan dalam mendampingi anak, padahal orang tua memiliki kewajiban dalam membentuk, mengarahkan dan mendidik anak dengan cara sungguh-sungguh, agar anak menjadi lebih baik lagi. Berikut beberapa ungkapan orang tua terkait degan pembelajaran daring bersama anaknya;

...anak saya sering sekali menangis, saat mengalami kesulitan dalam menyelesaikan pekerjaan yang diberikan oleh guru di sekolah, sehingga saya kasihan dan bahkan sering memarahinya, apabila anak tak kunjung diam... (Kutipan ungkapan EF, 35 Tahun)

....Keadaan yang sama saya alami, ketika anak tidak juga mengerti dengan apa yang saya sampaikan dan ajarkan, sehingga saya juga memarahinya dan bahkan memukulnya... (Kutipan ungkapan IR, 26 Tahun)

Semestinya sebagai orang tua harus dapat memahami psikologis anaknya, agar anak tidak mengalami kesulitan dan mengalami gangguan jiwa, seperti stress dan kepanikan yang terusmenerus saat mengikuti proses pembelajaran secara daring. Orang tua tidak mempunyai waktu yang banyak untuk mendampingi anak pada saat proses pembelajaran daring, dikarenakan kebanyakan orang tua sibuk dengan pekerjaannya, sehingga kesibukan inilah yang menjadi salah satu masalah yang dihadapi saat masa pandemi Covid19. Orang tua harus berperan penting dalam proses pembelajaran daring, dikarenakan orang tua merupakan seorang guru pertama bagi anak-anaknya. Maka dari itu, orang tua harus selalu berusaha 
semaksimal mungkin untuk mendidik dan membimbing serta memberi contoh yang baik, ketika anak sedang melakukan pembelajaran daring yang dilakukan dari rumah (Irhamnna, 2016:62). Salah satu orang tua di kelurahan sumber harta yang mengungkapkan mengenai kurangnya waktu untuk membimbing anaknya belajar ialah:

... saya bekerja sebagi petani, dengan adanya pembelajaran

daring seperti ini, saya mengalami kesulitan dalam

mendampingi anak-anak untuk belajar dari rumah. Karna

separuh dari waktu dihabiskan untuk bekerja di sawah..

(Kutipan ungkapan VK, 28 Tahun)

Pada intinya banyak keluhan-keluhan yang di lontarkan para orang tua pada saat mendampingi anaknya belajar di rumah saat di laksanakannya sosialisasi. Dari sosialisasi inilah terbukanya cakrawala berfikir masyarakat dalam mengatasi kesulitan-kesulitan yang ada. Sehingga mereka lebih siap dalam menbersamai dan membantu anak untuk melakukan pembelajaran dari rumah selama musibah covid-19.

Dukungan orangtua atau wali murid sengatlah penting untuk keberlansungan pendidikan daring. Badan Penelitian, Pengembangan dan Perbukuan, Kementrian Pendidikan dan Kebudayaan (Kemdikbud) telah memaparkan 3 peran yang paling penting orangtua dalam mendampingi anak belajar secara daring di rumah yakni :1) Orangtua memastikan anak belajar daring dengan Aman, sebagai orangtua membantu anak agar dapat belajar dengan aman secara efektif, baik di sekolah maupun dirumah, baik secara langsung maupun daring. 2) Beri semangat anak untuk belajar secara daring, seperti yang di ketahui anak cenderung mudah bosan dan kehilangan semangatnya, oleh karena itu sebagai orang tua perlu medukung dengan memberikannya semangat. Jika belajar dirumah ciptakanlah suasana yang menyenangkan. 3) Hubungi guru, dalam pembelajaran daring orangtua berperan sebagai guru di rumah yang ikut menyampaikan materi kepada anak, apabila mengalami kendala terhadap pembelajaran, misalnya tidak memiliki waktu untuk mengajar anak, maka orangtua bias menghubungi guru atau Dinas Pendidikan setempat untuk menemukan solusi yang tepat. 
Dengan demikian dapat disimpukan, sebagai orang tua tidak hanya sebagai sosok yang hanya berfungsi sebagai pemenuh kebutuhan material saja. Kebutuhan immaterial juga harus mendapatkan porsi yang sama bahkan lebih. Tanpa pendampingan yang bagus dari orangtua, maka hasil dari bangku orang tua tidak akan berbekas dan bermakna dalam masyarakat. Sebab, kemampuan akademis yang mencakup seluruh aspek karakter bahkan jiwa dan raga, tidaklah semata-mata tanggung jawab sekolah (guru). Dan ini menjadi kunci bagi keberhasilan peserta didik menjadi SDM unggul.

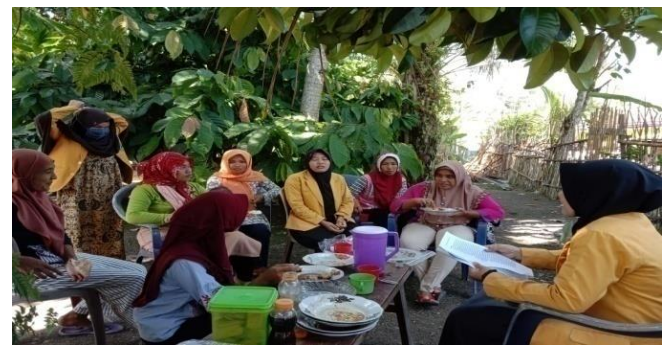

Gambar 3.

Kegiatan sosialisasi yang dilakukan penulis kepada orang tua

Kegiatan yang dilakukan berupa webinar dan penyuluhan langsung tersebut oleh peserta Kukerta merupakan upaya untuk menumbuhkan kesadaran para orangtua dalam medampingi pendidikan anak, serta memberikan motivasi kepada orang tua dalam membimbing anak-anaknya selama proses pembelajaran daring ini. Kita semua juga berdoa kepada Allah SWT, semoga pandemi Covid19 segera cepat berlalu agar anak-anak bisa mendapatkan pendidikan yang utuh dan mendapatkan pembelajaran yang efektif kembali serta dapat memberikan mindset kepada orang tua bahwa pentingnya pendampingan orang tua terhadap anak dalam proses pembelajaran, baik secara daring maupun luring orang tua memiliki kewajiban dalam mendidik anaknya.

\section{Simpulan}

Pembelajaran daring menjadikan semua element ikut berpartisipasi dalam proses pembelajaran diantaranya, guru, murid bahkan orang tua. Peran orang tua dalam proses pembelajaran daring sangatlah penting, orang tua sebagai pengawas, pembimbing serta pengajar dapat menjadikan pembelajaran daring berlangsung secara 
maksimal. Adanya pembelajaran daring saat ini, dapat mengembalikan kembali peran dan tanggung jawab orang tua sebagai madrasah pertama yang mempunyai kewajiban dalam mendidik anak-anaknya. Tidak hanya orang tua saja yang harus menerima adanya pembelajaran daring ini, guru juga harus mengondisikan bagaimana keadaan para orang tua yang notabennya pekerja petani dan buruh, serta yang hanya berpendidikan rendah. Forum edukasi melalui webinar menjadikan solusi kepada para orang tua untuk dapat memahami serta menjadikan pembelajaran daring ini berjalan sesuai dengan tujuan yang telah direncanakan. Orang tua juga dapat mengerti bahwa dengan kondisi seperti saat ini, menjadikan momen berharga bagi mereka dikarenakan orang tua dapat berperan sebagai guru pengganti di sekolah dan dapat mendidik serta mengajarkan anak mereka secara maksimal.

Adapaun langkah untuk memaksimalkan peningkatan peran orangtua dalam proses pembelajaran daring adalah dengan mensosialisasikan secara lansung kepada masyarakat Kelurahan Sumber Harta melalui webinar dan penyuluhan langsung. Dalam kesempatan ini para orangtua dapat berbincang secara lansung dan lebih efektif dalam membahas mengenai hal-hal yang perlu di perhatikan para orangtua dalam membimbing anak belajar dalam masa pandemi. Dengan memberikan arahan dan langkah-langkah yang harus dilakukan dalam mendampingi anak selama belajar daring yaitu 1) membuat rencana target belajar anak, 2) menjalankan kebiasaan yang sama dan ajarkan tanggung jawab, 3) sabar, 4) memanfaatkan aplikasi, 5) Mempelajari potensi anak. 


\section{DAFTAR PUSTAKA}

Agama, Departemen. 2017. Al-Qur'an dan Terjemahan. Jakarta: Maghfirah Pustaka.

Dewi, Wahyu Aji Fatma, "Dampak Covid-19 terhadap Implementasi Pembelajaran Daring di Sekolah Dasar", Edukatif: Jurnal Ilmu Pendidikan, Vol. 2, No. 1 (April 2020).

Euis Kurniati, dkk., "Analisis Peran Orang Tua dalam Mendampingi Anak di Masa Pandemi Covid-19”, Jurnal Obsesi, Vol. 5 No. 1 (Juni 2020)

Gorbalenya, A. E. et al. (2020) 'The species Severe acute respiratory syndrome-related coronavirus: classifying 2019-nCoV and naming it SARS-CoV-2', Nature Microbiology, 5(March).

Irhamna. Analisis Kendala yang Dihadapi Orang Tua dalam Menanamkan Akhlak dan Kedisiplinan Belajar Siswa Madrasah Darussalam Kota Bengkulu. Pembelajaran Alquran Hadis di Man Pagar Alam, 57-65. (2016).

Lia Nur Atiqoh Bela Dina, "Respon Orang Tua terhadap Pembelajaran Daring pada M asa Pandemi Covid-19", Thufuli: Jurnal Ilmiah Pendidikan Islam Anak Usia Dini, Vol. 2, No. 1 (Juli 2020).

Madi. Proses Sosialisasi Pendidikan. http://madigabungan.blogspot.co.id/2011/04/proses-sosialisasipendidikan.html (diakses 19 September 2020)

Moleong, Lexy, J. 2018. Metodologi Penelitian Kualitatif . PT Remaja Rosdakarya.

Siti Fadjryana Fitroh \& Sawitri, "Peran Orang Tua dalam Kegiatan Parenting guna Mengembangkan Kecerdasan Spiritual Anak di Sekolah", Jurnal Tunas Siliwangi, Vol. 5, No. 1 (April 2019).

Sofia Silvianita \& Eko Yulianto, "Webinar Sebagai Kegiatan Peningkatan Kompetensi Widyaiswara Pada Masa Pandemi Covid-19", Paedagoria: Jurnal Penelitian dan Pengembangan Kependidikan, Vol. 11 No. 2 (Juli 2020)

Subarto, "Momentum Keluarga Mengembangkan Kemampuan Belajar Peserta Didik Di Tengah Wabah Pandemi Covid-19", Adalah: Buletin Hukum dan Keadilan, Vol. 4, No. 1 (2020). 
174 Asih,dkk, Optimalisasi Peran Orang Tua dalam,...

Tabiin. Problematika Stay At Home Pada Anak Usia Dini Ditengah Pandemi. Jurnal Golden Age, Vol. 04 No. 1 Hal 190-200 EISSN: 2549-7367. (2020).

Wardhani, Tsaniya Zahra Yuthika \& Hetty Krisnani, "Optimalisasi Peran Pengawan Orang Tua dalam Pelaksanaan Sekolah Online di Masa Pandemi Covid-19", Prosiding Penelitian \& Pengabdian Kepada Masyarakat, Vol. 7, No. 1 (April 2020).

Wing-fai, Hong Kong Christopher Yu. Penutupan Sekolah Bikin $\begin{array}{llll}\text { Orang Tua } & \text { Stress } & \text {.2020. }\end{array}$

https://www.cnnindonesia.com/gaya-hidup/20200319130418284-484914/penutupan-sekolah-bikin-orang-tua-stres.

Winingsih, Endang. Peran Orang Tua dalam Pembelajaran Jarak Jauh. https://poskita.co/2020/04/02/peran-orang tua-dalampembelajaran-jarak-jauh. (diakses 7 September 2020) 